\title{
Viral and cellular biomarkers used for improving prevention and management of cervical cancer
}

\author{
Serban NASTASIA ${ }^{1,2}$, Ana-Catalina SAVU ${ }^{1,2}$, Anca POPA ${ }^{2}$, Anca Angela SIMIONESCU ${ }^{1,3}$, \\ Ana Maria Alexandra STANESCU ${ }^{1,4}$, Manuela Cristina RUSSU ${ }^{1,2}$ \\ 1 "Carol Davila" University of Medicine and Pharmacy, Bucharest, Romania \\ ${ }^{2}$ Department of Obstetrics and Gynecology, "Dr. Ion Cantacuzino" Clinical Hospital, Bucharest, Romania \\ ${ }^{3}$ Department of Obstetrics and Gynecology, Filantropia Clinical Hospital, Bucharest, Romania \\ ${ }^{4}$ Department of Familly Medicine, "Carol Davila" University of Medicine and Pharmacy, Bucharest, Romania
}

\begin{abstract}
Cervical cancer remains one of the preventable cause of women's death, the second most common cause of death in Europe. Several screening tests for precancerous lesions are available, including cervicovaginal cytology and screening of high-risk human papillomavirus (HPV) strains -16, 18, 31, 33. Cervical cytology (Babeş-Papanicolau smear test) remains the elected method for cervical cancer screening in many countries. Last decades, HPV DNA sequence was identified, including gene number and encoded proteins. HPV DNA gene expression involves the use of multiple promoters and complex patterns of splicing, which served as a model for the elaboration of cellular and molecular biomarkers for the identification. Herein, we present the usefulness and efficiency of viral and cellular biomarkers in improving the diagnosis and managing precursor lesions of cervical cancer.

Viral and cellular biomarkers can help differentiating low-grade lesion leading to a better diagnosis. HPV DNA tests, although a primary screening method in actual guidelines, can serve as a better screening test method. Other viral biomarkers that include E6 and E7 mRNA testing and determining the methylation of viral genes have good test screening results. Cellular biomarkers such as the immunocytochemical staining of p16INK4a, alone or combined with the proliferation marker Ki-67, can reveal anomalies in the cell cycle. The E4 protein, strongly expressed in productive infections, can prove a transforming infection when it is absent.

In recent years, detection of the TERC gene and oncogenetic microRNAs expressed early in carcinogenesis before clinical findings show great promise in differentiating lesions likely to progress to cancer.

In conclusion, biomarkers are more powerful instruments to enhance early pre-cervical cancer lesions diagnosis, which allow better prognosis and more reliable treatment.
\end{abstract}

Keywords: cervical cancer screening, E6 mRNA, E7 mRNA, p16INK4a, Ki-67

\section{INTRODUCTION}

Cervical cancer remains the second most common cause of women's death in Europe (1). Romania exhibits a mortality four times higher than Western Europe
(2). The persistence of Human Papilloma Virus (HPV) infection is responsible for over $99 \%$ of cervical cancer cases (3). Nevertheless, most HPV-induced lesions will not progress to cancer (4). Genital HPV infection is the most frequent sexually transmitted infection globally, 
and most sexually active women will be infected with HPV at some periods in their lives (5). HPV is a group of more than 200 related viruses, and at least 40 types infect the genital female tract (6); about 14 types are considered oncogenic, frequently HPV 16, 18, 31, 33. HPV is a small, non-enveloped, epitheliotropic viruses from the Papillomaviridae family with approximately 8 Kbp circular double-stranded DNA $(7,8)$.

The genome encodes six early proteins (E1, E2, E4, E5, E6 and E7) that are responsible for virus replication and two late proteins ( $\mathrm{L} 1$ and L2), which are the major and minor viral capsid proteins, respectively (9-11).

Carcinogenesis is a complex process from the precancerous lesion (high-grade squamous intraepithelial lesion (H-SIL), low-grade squamous intraepithelial lesion (L-SIL) to cancer. Last decades, HPV DNA sequence was identified, including gene number and encoded proteins. HPV DNA gene expression involves the use of multiple promoters and complex patterns of splicing, which served as a model for the elaboration of cellular and molecular biomarkers for the identification

Screening for precancerous lesions provides an excellent window for clinical prevention, diagnosis, and optimal treatment. Last decades, the natural history of cervical cancer, genomic and proteomic human papillomavirus (HPV) identification and vaccination may contribute largely to understand this pathology.

LAST Project established new classification criteria for cervical squamous cancer, which is classified into low-grade squamous intraepithelial lesions (LSIL) and high-grade squamous intraepithelial lesions (HSIL). LSIL represents non-carcinogenic human papillomavirus (HPV), resolved without treatment. LSIL is the same as cervical intraepithelial neoplasia (CIN) I in the traditional CIN classification standard. HSIL (same as CIN II and III) is a precancerous lesion and often requires surgical intervention to inhibit further progression to cervical squamous cell cancer. Comparing triage algorithms using HPV DNA genotyping, HPV E7 mRNA detection and cytology in high-risk HPV DNA-positive women was reported (12).

If high-grade squamous intraepithelial lesion (HSIL) and Atypical Squamous Cells, Cannot Rule Out High Grade Squamous Intra-epithelial Lesion (ASC-H) lesions will be immediately sent for colposcopy, atypical squamous cell indetermined signification (ASC-US) and lowgrade squamous intraepithelial lesion (LSIL) results require appropriate triage methods (13). Even though new screening and diagnostic technologies, viral and cellular biomarkers, are rapidly emerging, cytology remains the preferred method in many states. Despite its low sensitivity (53\%), repeat cytology at low intervals ensures its efficacy (14).

Therefore, more objective (viral, molecular) triage markers are suitable for automated and standardized screening processing.
Herein, we present the usefulness and efficiency of viral and cellular biomarkers in improving the diagnosis and the management of precursor lesions of cervical cancer.

\section{VIRAL BIOMARKERS}

\section{HPV DNA testing}

This is the most used triage method worldwide (15). HPV detection increases with disease severity (16). Low-grade disease are typically characterized by highrisk HPV types, including HPV 16 (3.2\%), 18 (1.4\%), 31 $(0.8 \%)$, and $58(0.7 \%)$. HPV high-risk types are founded in $50-70 \%$ of CIN1/LSIL (i.e. low-grade neoplasia). In CIN2, there is $85 \%$ positivity for HPV and in CIN3 and invasive cervical cancer, the HPV positivity rises to between $90 \%$ and $100 \%$ (17).

HPV DNA test advantage includes high sensitivity and similar specificity (96\% versus 53\%, 90\% versus $96 \%$ respectively) and the objective and reproducible result (18). Two technologies have been approved for HPV DNA testing: genomic amplification through polymerase chain reaction (PCR) and signal amplification hybridization for HPV (digene hybrid capture 2 - hc2). HPV (Digene Hybrid Capture 2 - hc2 is the gold standard for new technologies, as they must fulfil criteria in comparison to hc2: similar sensitivity, specificity and inter-and intralaboratory reproducibility (19). New guidelines recommend HPV DNA testing as a primary screening at a five-year interval (20). Still, despite the high sensitivity of this test, it cannot differentiate between a transitory and a persistent HPV infection, and it is imperative to be combined with cytology (21).

The production of new viral particles characterizes a transitory, productive HPV infection, thus by the expression of the late genes $\mathrm{L} 1$ and $\mathrm{L} 2$, which are necessary for viral assembly. Late region methylation, with the consecutive inactivation of the L1 and L2 genes, reveals the decrease of viral copies production and potential evolution to precursor and invasive lesions; it is a potential triage biomarker (22).

Methylation tests can also be applied for the host's genes (determination of FAM19A4 and has-mir-124-2 hypermethylation) (23) or simultaneously for the viral and host DNA (the S5 panel for methylation of late regions of HPV 16, 18, 31, 33 and the host gene EPB41L3) (24).

\section{E6 and E7 messenger RNA testing}

Another potential marker of a transforming infection is E6 and E7 messenger RNA testing. Hyperexpression of these two oncoproteins in persistent infections leads to deregulation of the cell cycle and progression to invasive lesions (20). Studies have shown that mRNA 
testing is appropriate as a triage method for precursor lesions (20) and a primary screening (25). Many reports have shown that the level of hrHPV E6/E7 transcripts correlates with severity of histological abnormality (26-28).

\section{CELLULAR BIOMARKERS}

The p16 $16^{\text {INK4a }}$ protein is a cell cycle inhibitory molecule - a stress stimulus induces it to block the inactivation of the tumor suppressor protein pRb (Retinoblastoma protein). The E7 oncoprotein induces such a stress stimulus and, at the same time, inactivates $\mathrm{pRb}$. The result is the accumulation of $\mathrm{p} 16^{\text {INK4a }}$ as well as the continuation of cell division (29).

p16 ${ }^{\text {INK4a }}$ can be used in triaging ASC-US and LSIL cytology, alone and combined with $\mathrm{Ki}-67$, a proliferation marker that is present in all phases of the cell cycle with the exception of $\mathrm{G}_{0}$ (30). A meta-analysis of Peeters et al. (2019) shows that, when compared to DNA testing, p16 and p16/Ki-67 double staining have a lower sensitivity, but higher specificity in triaging ASC-US and LSIL lesions, having the potential of limiting the number of unnecessary interventions (31).

p16 /Ki-67 double staining test in Romania is known as commercial CINTEC PLUS or CIN2+ tests.

Determining the E4 biomarker simultaneously with MCM (minichromosome maintenance protein) relies on a similar principle. The E4 protein is abundantly expressed in productive infections, but MCM is a surrogate marker for E6/E7 expression. These two molecules are seldom found in large quantities in the same cell at the same time, which serves a promising principle for a new triage test (32).

\section{OTHER TECHNOLOGIES}

Detection of the TERC gene from cytology specimens, which is early expressed in carcinogenesis along with the amplification of the $3 q$ chromosomal arm, has proved high sensitivity and specificity in differentiating high-grade from low-grade lesions, and it could be useful in triaging ASC-US and LSIL lesions (33).

MicroRNAs (miRNAs) are small RNA molecules that have a role in modulating gene expression (20). E6 and E7 oncogenes of HPV16 and 18 amplify the expression of oncogenic miRNAs, which can be found in an increasing proportion as the lesion severity increases (34).

Techniques that allow self-sampling for HPV testing are a potential solution for the low participation in screening programs; their sensitivity and specificity for CIN2+ diagnosis have similar values to the samples taken by a clinician: $93,1 \%$ versus $96,1 \%, 94,0 \%$ versus $94,3 \%$, respectively (35).

\section{CONCLUSIONS}

Biomarkers are helpful for the improvement of cervical cancer screening and management. However, there are not routinely introduced due to advanced technologies and high costs. HPV DNA testing is increasingly used as a primary screening method in cervical cancer and precursor lesions. Still, repeated Babes-Papanicolau cytology, a cost-effective triage strategy, remains the elected method in many countries as biomarkers serve to complete it in better diagnosing equivocal and abnormal results.

Conflict of interest: none declared Financial support: none declared

\section{REFERENCES}

1. Ferlay J, Steliarova-Foucher E, LortetTieulent J, Rosso S, Coebergh JW, Comber $\mathrm{H}$, Forman D, Bray F. Cancer incidence and mortality patterns in Europe: estimates for 40 countries in 2012. Eur J Cancer. 2013 Apr;49(6):1374-403.

2. Bray F, Ferlay J, Soerjomataram I, Siegel $\mathrm{RL}$, Torre LA, Jemal A. Global cancer statistics 2018: GLOBOCAN estimates of incidence and mortality worldwide for 36 cancers in 185 countries. CA Cancer J Clin. 2018 Nov;68(6):394-424.

3. Walboomers JM, Jacobs MV, Manos MM, Bosch FX, Kummer JA, Shah KV, Snijders PJ, Peto J, Meijer CJ, Muñoz N. Human papillomavirus is a necessary cause of invasive cervical cancer worldwide. J Pathol. 1999 Sep;189(1):12-9.

4. Ostör AG. Natural history of cervical intraepithelial neoplasia: a critical review. Int J Gynecol Pathol. 1993 Apr;12(2):186-92.
5. Dunne EF, Unger ER, Sternberg $M$, McQuillan G, Swan DC, Patel SS, Markowitz LE Prevalence of HPV infection among females in the United States. JAMA. 2007 Feb 28;297(8):813-9.

6. Muñoz N, Bosch FX, de Sanjosé S, Herrero R, Castellsagué X, Shah KV, Snijders PJ, Meijer CJ, International Agency for Research on Cancer Multicenter Cervical Cancer Study Group Epidemiologic classification of human papillomavirus types associated with cervical cancer. N Engl J Med. 2003 Feb 6; 348(6):518-527.

7. Woodman CB, Collins SI, Young LS The natural history of cervical HPV infection: unresolved issues. Nat Rev Cancer. 2007 Jan;7(1):11-22.

8. Fernandes J, Carvalho M, de Fernandes T, et al. Prevalence of human papillomavirus type 58 in women with or without cervical lesions in northeast Brazil. Ann Med Health Sci Res. 2013;3(4):504-510.

9. Schiller JT, Lowy DR. Understanding and learning from the success of prophylactic human papillomavirus vaccines. Nat Rev Microbiol. 2012 Oct;10(10):681-92.

10. Chen XS, Garcea RL, Goldberg I, Casini G, Harrison SC. Structure of small virus-like particles assembled from the L1 protein of human papillomavirus 16. Mol Cell. 2000 Mar;5(3):557-67.

11. Rubio I, Seitz H, Canali E, Sehr P, Bolchi A, Tommasino M, Ottonello S, Müller M. The $\mathrm{N}$-terminal region of the human papillomavirus L2 protein contains overlapping binding sites for neutralizing, cross-neutralizing and non-neutralizing antibodies. Virology. 2011 Jan 20;409(2):348-59.

12. Luttmer R, Berkhof J, Dijkstra MG, van Kemenade FJ, Snijders PJ, Heideman DA, 
Meijer CJ. Comparing triage algorithms using HPV DNA genotyping, HPV E7 mRNA detection and cytology in high-risk HPV DNA-positive women. J Clin Virol. 2015 Jun;67:59-66.

13. Arbyn M, Buntinx F, Van Ranst M, Paraskevaidis E, Martin-Hirsch P, Dillner J. Virologic versus cytologic triage of women with equivocal Pap smears: a meta-analysis of the accuracy to detect high-grade intraepithelial neoplasia. J Natl Cancer Inst. 2004 Feb 18;96(4):280-93.

14. MacDonald CF. Assessing secondary prevention methods for cervical cancer: costs and benefits in managed care. Am J Manag Care. 2008 Jun;14(6 Suppl 1):S185-92.

15. Dillner J, Rebolj M, Birembaut P, Petry KU, Szarewski A, Munk C, et al.; Joint European Cohort Study. Long term predictive values of cytology and human papillomavirus testing in cervical cancer screening: joint European cohort study. BMJ. 2008 Oct 13;337:a1754.

16. Bruni L, Diaz M, Castellsagué X, Ferrer E, Bosch FX, de Sanjosé S. Cervical human papillomavirus prevalence in 5 continents: meta-analysis of 1 million women with normal cytological findings. $J$ Infect Dis. 2010 Dec 15;202(12):1789-99.

17. Guan P, Howell-Jones R, Li N, Bruni L, de Sanjosé S, Franceschi S, Clifford GM. Human papillomavirus types in 115,789 HPV-positive women: a meta-analysis from cervical infection to cancer. Int $J$ Cancer. 2012 Nov 15;131(10):2349-59.

18. Cuzick J, Clavel C, Petry KU, Meijer CJ, Hoyer H, Ratnam S, Szarewski A, Birembaut P, Kulasingam S, Sasieni P, Iftner T. Overview of the European and North American studies on HPV testing in primary cervical cancer screening. Int $J$ Cancer. 2006 Sep 1;119(5):1095-101.

19. Meijer CJLM, Berkhof J, Castle PE, Hesselink AT, Franco EL, Ronco G, et al. Guidelines for human papillomavirus DNA test requirements for primary cervical cancer screening in women 30 years and older. Int $J$ Cancer. 2009 Feb 1;124(3):516-20.

20. Macedo ACL, Gonçalves JCN, Bavaresco DV, Grande AJ, Chiaramonte Silva N, Rosa MI. Accuracy of mRNA HPV Tests for Triage of Precursor Lesions and Cervical Cancer: A Systematic Review and Meta-Analysis. J Oncol. 2019 Jun 11;2019:6935030.

21. Bhatla N, Singhal S. Primary HPV screening for cervical cancer. Best Pract Res Clin Obstet Gynaecol. 2020 May;65:98-108.

22. Simanaviciene V, Popendikyte V, Gudleviciene Z, Zvirbliene A. Different DNA methylation pattern of HPV16, HPV18 and HPV51 genomes in asymptomatic HPV infection as compared to cervical neoplasia. Virology. 2015 Oct;484:227-233.

23. Luttmer R, De Strooper LM, Berkhof J, Snijders PJ, Dijkstra MG, et al. Comparing the performance of FAM19A4 methylation analysis, cytology and HPV16/18 genotyping for the detection of cervical (pre)cancer in high-risk HPV-positive women of a gynecologic outpatient population (COMETH study). Int J Cancer. 2016 Feb 15;138(4):992-1002.

24. Lorincz AT, Brentnall AR, ScibiorBentkowska D, Reuter C, Banwait R, Cadman L, et al. Validation of a DNA methylation HPV triage classifier in a screening sample. Int J Cancer. 2016 Jun 1;138(11):2745-51.

25. Heideman DAM, Hesselink AT, van Kemenade FJ, Iftner T, Berkhof J, Topal F, et al. The Aptima HPV Assay Fulfills the Cross-Sectional Clinical and Reproducibility Criteria of International Guidelines for Human Papillomavirus Test Requirements for Cervical Screening. J Clin Microbiol. 2013 Nov;51(11):3653-7.

26. Coquillard G, Palao B, Patterson BK. Quantification of intracellular HPV E6/E7 mRNA expression increases the specificity and positive predictive value of cervical cancer screening compared to HPV DNA. Gynecol Oncol. 2011 Jan;120(1):89-93.

27. Rijkaart DC, Heideman DA, Coupe VM, et al. High-risk human papillomavirus (hrHPV) E6/ E7 mRNA testing by PreTect HPV-Proofer for detection of cervical high-grade intraepithelial neoplasia and cancer among hrHPV DNA-positive women with normal cytology. J Clin Microbiol. 2012 Jul;50(7):2390-6.

28. Mills AM, Dirks DC, Poulter MD, Mills SE, Stoler MH. HR-HPV E6/E7 mRNA In Situ
Hybridization: Validation Against PCR, DNA In Situ Hybridization, and p16 Immunohistochemistry in 102 Samples of Cervical, Vulvar, Anal, and Head and Neck Neoplasia. Am J Surg Pathol. 2017 May;41(5):607-615.

29. Klaes R, Benner A, Friedrich T, Ridder R, Herrington S, Jenkins D, et al. p16INK4a Immunohistochemistry Improves Interobserver Agreement in the Diagnosis of Cervical Intraepithelial Neoplasia. Am J Surg Pathol. 2002 Nov;26(11):1389-99.

30. Stevenson A, Kavanagh K, Pan J, Stevenson L, Griffin H, Doorbar J, et al. Risk stratification of cervical disease using detection of human papillomavirus (HPV) E4 protein and cellular MCM protein in clinical liquid based cytology samples. J Clin Virol. 2018 Nov; 108:19-25.

31. Peeters E, Wentzensen N, Bergeron C, Arbyn M. Meta-analysis of the accuracy of p16 or p16/Ki-67 immunocytochemistry versus HPV testing for the detection of CIN2+/CIN3+ in triage of women with minor abnormal cytology. Cancer Cytopathol. 2019 Mar;127(3):169-180.

32. Jiang J, Wei L-H, Li Y-L, Wu R-F, Xie X, Feng Y-J, et al. Detection of TERC Amplification in Cervical Epithelial Cells for the Diagnosis of High-Grade Cervical Lesions and Invasive Cancer: A Multicenter Study in China. J Mol Diagn. 2010 Nov;12(6):808-17.

33. Sharma G, Dua P, Agarwal S. A Comprehensive Review of Dysregulated miRNAs Involved in Cervical Cancer. Curr Genomics. 2014 Aug;15(4):310-23.

34. Wang X, Wang H-K, Li Y, Hafner M, Banerjee NS, Tang S, et al. microRNAs are biomarkers of oncogenic human papillomavirus infections. Proc Natl Acad Sci. 2014 Mar 18;111(11):4262 LP - 4267.

35. Polman NJ, Ebisch RMF, Heideman DAM, Melchers WJG, Bekkers RLM, Molijn AC, et al. Performance of human papillomavirus testing on self-collected versus cliniciancollected samples for the detection of cervical intraepithelial neoplasia of grade 2 or worse: a randomised, paired screenpositive, non-inferiority trial. Lancet Oncol. 2019 Feb;20(2):229-238. 